\title{
A Rare Cause of Headache: Aspergillus Sinusitis
}

\section{Nadir Bir Baş Ağrısı Nedeni: Aspergillus Sinüziti}

\author{
Şehnaz Arıc1, Özge Özen Gökmuharremoğlu, Behiye Özer \\ Katip Çelebi University, Atatürk Training and Research Hospital, Clinic of Neurology, İzmir, Turkey
}

\section{Summary}

Fungal sinusitis is a frequently observed entity in immunosuppressed individuals and can be fatal. Surgical debridement, sinus aeration, and medical treatment are recommended in its management. Herein, a case of fungal sinusitis is reported in a patient who presented with headache.

Keywords: Fungal sinusitis, headache, aspergillus

$\ddot{O} \mathbf{z}$

Fungal sinüzit sıklıkla immünsupresif bireylerde gözlenen ve mortal seyredebilen bir tablodur. Fungal sinüzit tedavisinde cerrahi debridman, sinüs havalandırılması ve medikal tedavi önerilmektedir. Baş ağrısı ile başvuran hastada fungal sinüzit olgusu sunulmuştur.

Anahtar kelimeler: Fungal sinüzit, baş ağrısı, aspergillus

\section{Introduction}

Fungal sinusitis is a frequently observed entity in immunosuppressed individuals and can be fatal . It can be divided into two groups, invasive and non-invasive disease. Aspergillus species are the most commonly isolated pathogen in all clinical forms of the disease. Surgical debridement, sinus aeration, and medical treatment are recommended in its management (1). Fungal sinusitis, which is rare in etiology, was observed in a patient who presented with headache.

\section{Case Report}

A XXX aged 60 years presented to our clinic with a 15day history of throbbing headache, which started from the neck and radiated to the right eye, that worsened with lying down, sometimes on awakening, and had a partial response to analgesics. The patient had undergone magnetic resonance imaging (MRI) examination and was diagnosed as having acute sinusitis in the right sphenoid sinus. The patient had been advised to attend our clinic because the patient had not responded to treatment. The neurologic examination and routine tests revealed no abnormality. The erythrocyte sedimentation rate (ESR) was 27 and C-reactive protein (CRP) level was $4.1 \mathrm{mg} / \mathrm{dL}$. Paranasal sinus computed tomography (CT) revealed hyperdense, irregular soft tissue density that caused loss of aeration in the right sphenoid sinus (Figure 1a, 1b). Fungal infection was suspected in the differential diagnosis. Obliteration of the right sphenoid sinus and hypointense area with high concentrations of calcium and mineral salts were consistent with fungus ball (mycetoma) in the MRI of the face (Figure 2a, 2b). The patient was referred to the Ear, Nose and Throat (ENT) Clinic. Endoscopic sinus surgery was performed. Pathology examination with Periodic acid Schiff (PAS) staining revealed a large number of hyphae of Aspergillus, mycetoma, and inflamed sinus mucosa. Antifungal therapy was not recommended in the post-operative period because the disease was detected to be noninvasive. The patient was postoperatively evaluated at 3, 6 and 12 months and no pathology was detected in physical examinations or sinus CT scans. 


\section{Discussion}

Fungal sinusitis often occurs in the presence of predisposing factors such as allergy, long-term antibiotic treatment, local or systemic steroid use, chronic sinusitis, diabetes, malignancy, and suppression of the immune system (1). Fungal sinusitis was observed in our patient although there were no risk factors.

Fungal sinusitus has 2 subtypes, invasive (acute fulminant and chronic silent) and noninvasive (mycetoma and allergic fungal sinusitis) (2). The acute fulminant type is lethal and often observed in immunocompromised individuals $(1,2)$. The
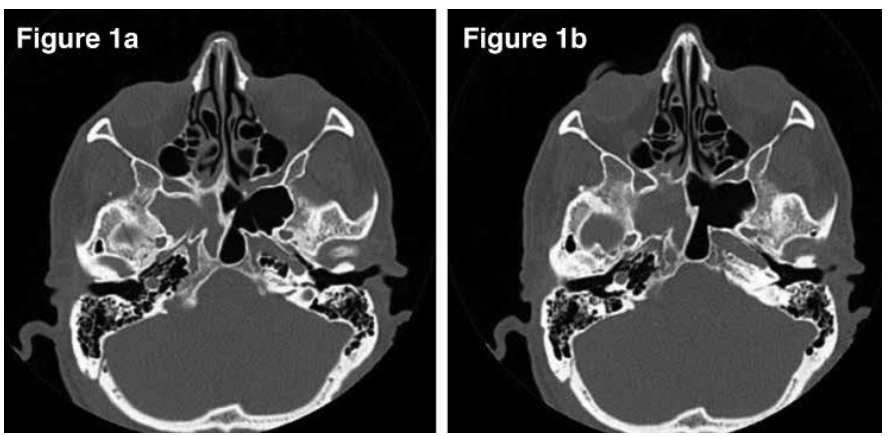

Figure 1. $(\mathrm{a}, \mathrm{b})$ The paranasal sinuses computed tomography that shows hyperintense soft tissue density causes aeration loss in right sphenoid sinuses
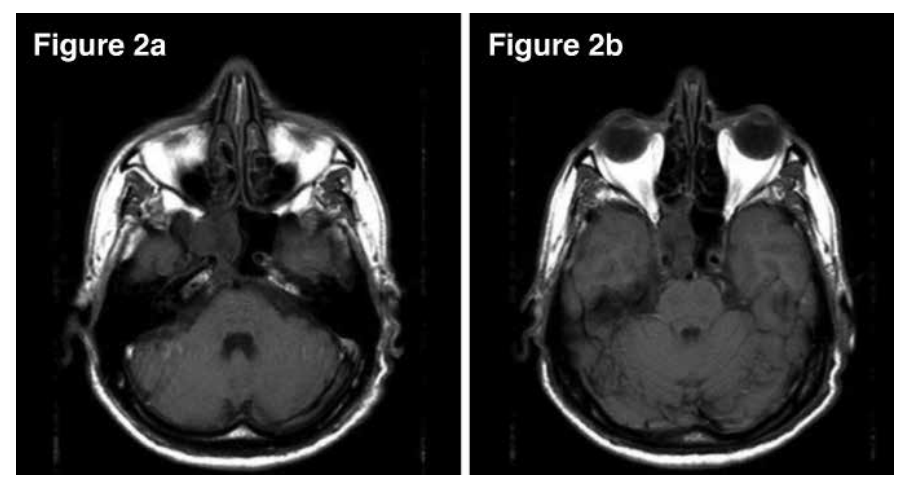

Figure 2. (a, b) The obliteration in right sphenoid sinuses and hypodens area deposition of calcium and mineral salts, fungus ball (mycetoma) in facial magnetic resonance imaging agents are generally Mucor, Rhizopus and Aspergillus species (2). Widespread tissue necrosis and fungal vascular invasion is observed in its pathophysiology (1). The chronic silent type is benign and may also be observed in normal individuals. Mycetoma, which is included in the noninvasive group, is caused by Aspergillus species, and involves limited proliferation of fungal elements in a single sinus. There is no immune reaction against fungi (2). Immunosuppressant agents are given during the postoperative period because of the development of type I and III hypersensitivity reactions against the fungal antigens in atopic individuals in allergic fungal sinusitis (3).

Complications during fungal sinusitis are due to tissue and bone damage caused by cytotoxic metabolites that form during the growth of micelles (4). Cranio-orbital invasion is most common in sphenoidal aspergillosis (1). Pain in the head; face and eye; ophthalmoplegia; proptosis; optic neuropathy; orbital apex and cavernous sinus syndrome; frontal lobe specific focal neurologic deficits; and seizures may occur in patients (1).

Surgical debridement, sinus aeration, and medical treatment are recommended in the management of fungal sinusitis (1).

Concept: Şehnaz Arıcı, Özge Özen Gökmuharremoğlu, Behiye Özer, Design: Şehnaz Arıcı, Özge Özen Gökmuharremoğlu, Behiye Özer, Data Collection or Processing: Özge Özen Gökmuharremoğlu, Şehnaz Arıc1, Behiye Özer, Analysis or Interpretation: Şehnaz Arıc1, Özge Özen Gökmuharremoğlu, Behiye Özer, Literature Search: Şehnaz Arıc1, Author: Şehnaz Arıc1, Peer-review: External and Internal peer-reviewed. Conflict of Interest: The authors did not report any conflict of interests regarding this article. Financial support: We have received no financial support for this study.

\section{References}

1. Apuhan T, Küçükbayrak A, Hakyemez İ. Fungal sinusitis in immunocompromised hosts JAMA 2011;5:1577-1580.

2. Montone KT, Livolsi VA, Feldman MD, Palmer J, Chiu AG, Lanza DC, Kennedy DW, Loevner LA, Nachamkin I. Fungal rhinosinusitis: a retrospective microbiologic and pathologic review of 400 patients at a single university medical center. Int J Otolaryngol 2012;2012:684835.

3. Glass D, Amedee RG. Allergic fungal rhinosinusitis: a review. Ochsner J 2011;11:271-275.

4. Devèze A, Facon F, Latil G, Moulin G, Payan-Cassin H, Dessi P. Cavernous sinus thrombosis secondary to non-invasive sphenoid aspergillosis Rhinology 2004;43:152-155. 